\title{
FIRST TURTLE FROM THE IPUBI FORMATION (EARLY CRETACEOUS), SANTANA GROUP, ARARIPE BASIN, BRAZIL
}

\author{
GUSTAVO RIBEIRO OLIVEIRA \\ Departamento de Geologia e Paleontologia, Universidade Federal do Rio de Janeiro/Museu Nacional, Quinta da Boa Vista \\ $\mathrm{s} / \mathrm{n}^{\circ}, 20940-040$, Rio de Janeiro, RJ, Brazil. gustavoliveira@ gmail.com \\ ANTÔNIO ÁLAMO FEITOSA SARAIVA \\ Departamento de Ciências Biológicas, Universidade Regional do Cariri, Rua Coronel Antônio Luís, 1161, 63105-000, \\ Crato, CE, Brazil.alamocariri@yahoo.com.br \\ HELDER DE PAULA SILVA \\ Curso de Ciências Biológicas - CSE, Universidade do Grande Rio, Rua Professor José de Souza Herdy, 1160, 25071-202, \\ Duque de Caxias, RJ, Brazil. helder@acd.ufrj.br \\ JOSÉ ARTUR FERREIRA GOMES DE ANDRADE \\ Centro de Pesquisas Paleontológicas da Chapada do Araripe, Departamento Nacional de Produção Mineral, Praça da Sé, \\ 63100-440, Crato, CE, Brazil.artur.andrade@dnpm.gov.br \\ ALEXANDER WILHELMARMIN KELLNER
Departamento de Geologia e Paleontologia, Universidade Federal do Rio de Janeiro/Museu Nacional, Quinta da Boa Vista
$\mathrm{s} / \mathrm{n}^{\circ}$, 20940-040, Rio de Janeiro, RJ, Brazil. kellner@mn.ufrj.br
}

ABSTRACT - Up to date turtle remains from the Early Cretaceous Santana Group are known only to the Crato and Romualdo formations (Aptian-Albian) that have yielded five species: Araripemys barretoi Price, 1973; Santanachelys gaffneyi Hirayama, 1998; Brasilemys josai Lapparent de Broin, 2000; Cearachelys placidoi Gaffney, Campos \& Hirayama, 2001 and Euraxemys essweini Gaffney, Tong \& Meylan, 2006. Except for A. barretoi, known from both, the Romualdo and Crato formations, all other turtle taxa are restricted to the Romualdo Formation. Fragments of the skull, an incomplete lower jaw and carapace of the first turtle remains from the Ipubi Formation are reported here. This material was collected in the shales above the gypsum layer, close to the contact with the Romualdo Formation (Aptian-Albian). Compared to other turtles from the Santana Group, this specimen is referred to Pelomedusoides, excluding Araripemys and Brasilemys, based on the following characteristics: absence of a cavum pterygoidei, absence of cervical scute, absence of fontanels in the carapace, contact between nuchal and first peripheral, and absence of nuchal emargination.

Key words: Early Cretaceous, Araripe Basin, Santana Group, Ipubi Formation, Pleurodira, Pelomedusoides.

RESUMO - Até o momento, restos de tartarugas do Grupo Santana (Cretáceo Inferior) têm sido descritos apenas para as formações Crato e Romualdo (Aptiano-Albiano) e cinco espécies são conhecidas: Araripemys barretoi Price, 1973; Santanachelys gaffneyi Hirayama, 1998; Brasilemys josai Lapparent de Broin, 2000; Cearachelys placidoi Gaffney, Campos \& Hirayama, 2001 and Euraxemys essweini Gaffney, Tong \& Meylan, 2006. À exceção de A. barretoi, que é encontrada nas formações Crato e Romualdo, todas as outras espécies de tartarugas são restritas a Formação Romualdo. Restos da primeira tartaruga da Formação Ipubi, compostos por fragmentos de crânio, mandíbula e carapaça, são aqui reportados. O espécime foi coletado nos folhelhos betuminosos, acima da camada de gipsita, próximo ao contato com a Formação Romualdo (Aptiano-Albiano). Comparado com as outras tartarugas do Grupo Santana, este espécime é referido a Pelomedusoides, excluindo Araripemys e Brasilemys, baseado nas seguintes características: ausência do cavum pterigoidei, ausência de escudo cervical, ausência de fontanelas na carapaça, contato entre a placa nucal e a primeira placa periferal e ausência de entalhe na placa nucal.

Palavras-chave: Cretáceo Inferior, bacia do Araripe, Grupo Santana, Formação Ipubi, Pleurodira, Pelomedusoides.

\section{INTRODUCTION}

The Araripe Basin is located in northeastern Brazil between the states of Ceará, Piauí and Pernambuco (Figure 1). The Crato and Romualdo formations (Santana Group, see details in
Neumann \& Cabrera, 1999; Valença et al., 2003) that comprise the most fossiliferous strata of this basin, are famous worldwide for the diverse and exquisitely well preserved fossil assemblages (e.g. Maisey, 1991). These two different lagerstätten were formed during the Lower Cretaceous, Aptian/Albian (Pons et al., 1990; 

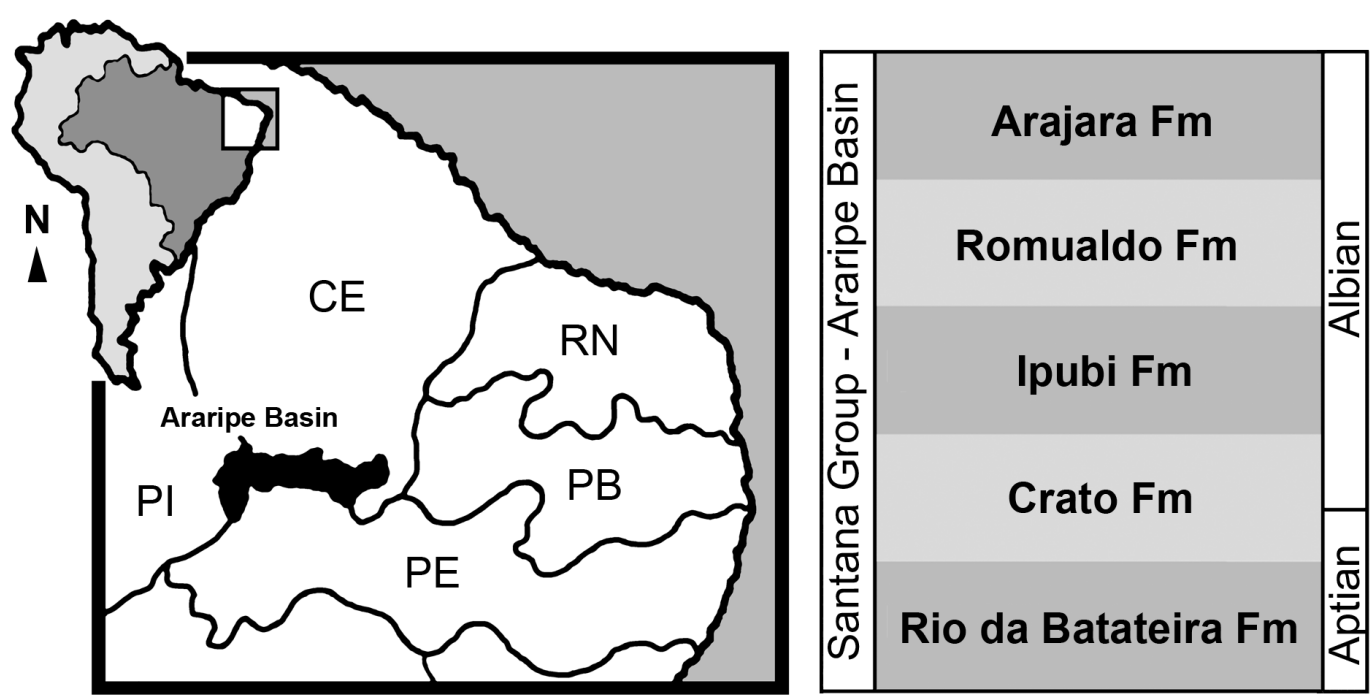

Figure 1. Map showing the location of the Araripe Basin and the formations that compose the Santana Group. Ages based on Valença et al. (2003).

Ponte \& Ponte Filho, 1996; Neumann \& Cabrera, 1999) and have yielded several fossil reptiles such as turtles, dinosaurs, pterosaurs, and crocodylomorphs (e.g. Kellner, 1987; Kellner \& Campos, 1999, 2000; Fara et al., 2005; Oliveira \& Romano, 2007).

Turtles from the Santana Group have been described from the Crato and Romualdo lagerstätten (Oliveira \& Kellner, 2005; Oliveira \& Romano, 2007; Oliveira et al., 2009) but none osteological evidence has been reported from the Ipubi Formation so far. Here we present the first turtle material from latter that increases the distribution of these reptiles in the Santana Group. Recently, Dentzien-Dias et al. (2010) published the first ichnological evidence of a swimming tetrapod, a footprint, in the Ipubi Formation (sensu Neumann \& Cabrera, 1999 and Valença et al., 2003) or Ipubi layers, Crato Formation (sensu Assine, 2007). These authors associated the morphology of this footprint as if it had been produced by the autopodium of a turtle while swimming. However, Dentzien-Dias et al. (2010) do not rule out the possibility of this footprint belonging to other tetrapod.

It should be noted that Fielding et al. (2005:1302) briefly mentioned one turtle from bituminous shales at Mina Pedra Branca, near Nova Olinda that was identified as cf. Araripemys; according to one author (JAFGA) this is the same specimen described here.

The specimen studied here is housed in the collection of the Centro de Pesquisas Paleontológicas da Chapada do Araripe of the Departamento Nacional de Produção Mineral, Crato, Ceará under the number CPCA 3560. It consists of crushed fragments of the skull, a partial lower jaw and the carapace. A cast of this material is housed at the Museu Nacional/UFRJ (MN 4122-V). Institutional abbreviations: CPCA, Centro de Pesquisas Paleontológicas da Chapada do Araripe of the Departamento Nacional de Produção Mineral (DNPM), Crato, Ceará; MN, Museu Nacional, Universidade Federal do Rio de Janeiro. Anatomical abbreviations: ang, angular; cos, costal bone; de, dentary; il, iliac scar; ne, neural bone; nu, nuchal bone; pe, peripheral bone; pt, pterygoid; py, pygal bone; qu, quadrate; spy, suprapygal bone; sur, surangular.

\section{GEOLOGICAL SETTING}

The Santana Group of the Araripe Basin is subdivided in five formations (Figure 1), named from base to top: Rio da
Batateira, Crato, Ipubi, Romualdo and Arajara formations (Neumann \& Cabrera, 1999; Valença et al., 2003). The Ipubi Formation is composed primarily of gypsum and anhydrite, with intercalated beds of black shales (Ponte \& Appi, 1990). With maximum thickness of $30 \mathrm{~m}$, the layers of gypsum are common in the area of Santana do Cariri, but are concentrated mostly in the western portion of the basin, from Ipubi to Araripina (Assine, 1992). According to Silva (1988) this evaporitic layer represents the climax of a sedimentary sequence in a lake, whose waters have become increasingly saline due to increased evaporation. In the strata of the Ipubi Formation are found remains of ostracods, fishes and fragments of leaves of Ginko sp. The specimen described here was collected in the shales above the gypsum layer (Figure 2), close to the contact with the Romualdo Formation, at the mine of Pedra Branca nearby the town of Nova Olinda in the State of Ceará, northeastern Brazil and it is the first osteological evidence of tetrapod to this deposit.

\section{SYSTEMATIC PALEONTOLOGY}

\author{
TESTUDINES Linnaeus, 1758 \\ CASICHELYDIAGaffney, 1975 \\ PLEURODIRACope, 1864 \\ PELOMEDUSOIDESCope, 1868 \\ Gen. et sp. indet. \\ (Figures 3-5; Table 1)
}

Material. CPCA 3560, crushed fragments of the skull, a partial lower jaw and the carapace; MN 4122-V, a cast of this material. Locality. Mine of Pedra Branca nearby the town of Nova Olinda, Ceará State, northeastern Brazil.

Stratigraphic unit. Ipubi Formation, Santana Group, Araripe Basin.

Age. Early Cretaceous.

Description. The skull in CPCA 3560 (Figure 3) is represented, as preserved, by left maxilla, pterygoid, quadrate and basisphenoid. The contacts among these elements are difficult to establish due to the poor preservation. The most important anatomical feature that can be determined is the absence of a cavum pterygoidei, that is also absent in Araripemys, Euraxemys and Cearachelys, contrasting to the condition observed in 


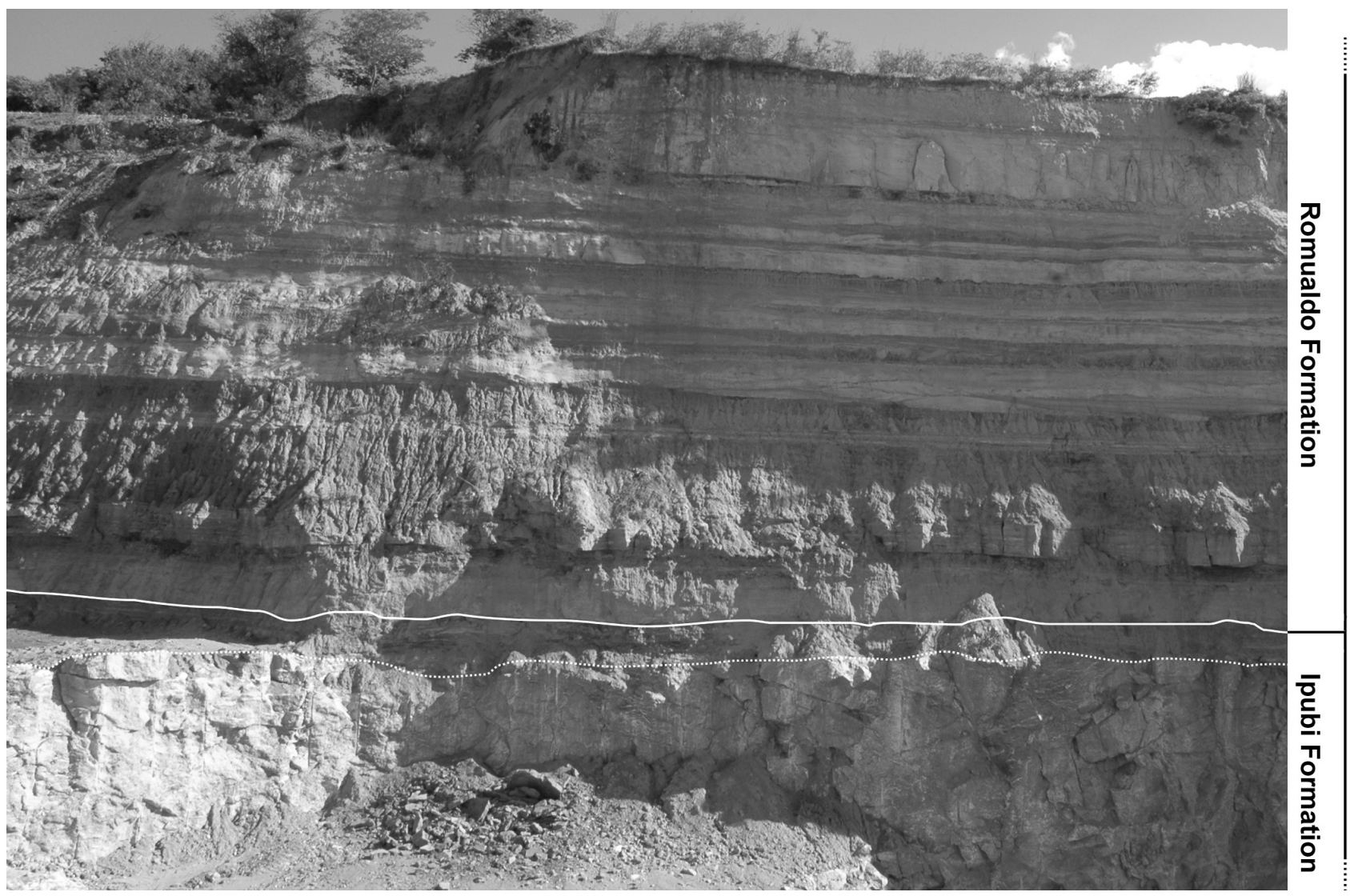

Figure 2. Outcrop at the Mina da Pedra Branca, Nova Olinda, Ceara State, showing contact of the Ipubi and Romualdo formations (thick line). The dotted line marks the contact between the black shale where the turtle specimens CPCA 3560 was collected and the gypsum layer.

Brasilemys and other podocnemidids (e.g. Gaffney et al., 2006; Meylan et al., 2009).

The lower jaw of the specimen is represented only by the dentary, surangular, and angular (Figure 3). The left ramus is almost complete and the right ramus is fragmented posteriorly. Unfortunately most of those elements are incomplete and do not provide any detailed information, except for the dentaries. These bones are nearly complete except for the posterior portion of the right one. They are anteriorly tall near the surangular, becoming progressively lower posteriorly. On each side they contact the surangular posteriorly and the angular posteroventrally. It is not clear if the dentaries are sutured in a midline symphysis (as in Araripemys, Euraxemys and Pelomedusa) or fused (as in bothremydids and podocnemidids). However, it is clear that the symphysis in CPCA 3560 is thickened in contrast to Araripemys and some chelids.

The only portion of the shell preserved in CPCA 3560 is the carapace (Figure 4), which is the most informative part of the material. On the counterpart of the slab of the specimen the impression of some peripheral bones are preserved (Figure 5). The carapace is uncrushed showing a rather smooth external surface, in contrast to the sculptured condition with marked pits observed in Araripemys barretoi Price, 1973 (see Meylan, 1996; Gaffney et al., 2006).

Due to the splitting of the material, some interior parts of the carapace are exposed. The axillary buttresses are visible below the costal 1 and medial to peripheral 3 on the right side (Figure 4). On the posterior portion of the carapace it is possible to see the iliac scar on costals 7 and 8 (Figure 5). The iliac scar is triradiated in dorsal view, with anterior, posterior, and posterolateral projections. This feature differs from the condition in non-Pelomedusoides pleurodires which lack well developed projections (Meylan, 1996; Lapparent de Broin \& Murelaga, 1999; De La Fuente \& Iturralde-Vinent, 2001).

The shell is oval, domed and incomplete. However CPCA 3560 is not as domed as in Cearachelys. There is no evidence of nuchal emargination on the anterior portion of carapace, as in Araripemys. The posterior portion of the carapace in CPCA 3560 is similar to Brasilemys and Euraxemys, being wider than in Cearachelys.

CPCA 3560 has a complete nuchal bone. At least five neural bones can be determined but the total number of neurals cannot be established. A triangular suprapygal is preserved. The pygal is also represented, partially in bone and partially as an imprint. The specimen has eight pairs of costals, and 11 peripherals bones.

The nuchal is a long element with the anterior border elongated as in Cearachelys, differing from Brasilemys, where this bone is approximately as wide as long. The nuchal contacts neural 1 posteriorly, costal 1 posterolaterally and peripheral 1 laterally. These features differ from Araripemys, where the first peripherals are greatly reduced and do not contact the nuchal (Meylan, 1996; Gaffney et al., 2006). No evidence of a cervical scale is observed in the Ipubi material, indicating that this element was absent in this taxon as in other Pelomedusoides (Gaffney et al., 2001, 2006).

There are no fontanels in CPCA 3560, which are also absent in Brasilemys, Euraxemys and Cearachelys, in contrast to the 
condition of Araripemys which has fontanels in the carapace and plastron (Price, 1973; Kischlat \& Campos, 1990; Schleich, 1990; Meylan, 1996; Oliveira \& Kellner, 2005, 2007; Gaffney et al., 2006).

In CPCA 3560 there is no evidence to determine whether the neural series is complete, as in Araripemys, Euraxemys and Cearachelys, or if the costal bones intervene between the last neural and the suprapygal, as in Brasilemys and other Pelomedusoides.

The first neural is similar to the one in Cearachelys and
Brasilemys, by being six sided and contacting neural 2 , the first costal, and by having short and paired contacts with the second costal. The second neural is quadrangular and has a wide contact with costal 2 . The third and fourth neurals are hexagonal. Neural 3 has a short contact with costal 2, and a wide contact with costal 3.Neural 4 contacts costals 3 and 4 .

The suprapygal has a triangular shape and contacts peripheral 11 and the pygal, there is no evidence that it contacts the last neural. The pygal bone is long and is represented by both bone and imprint.
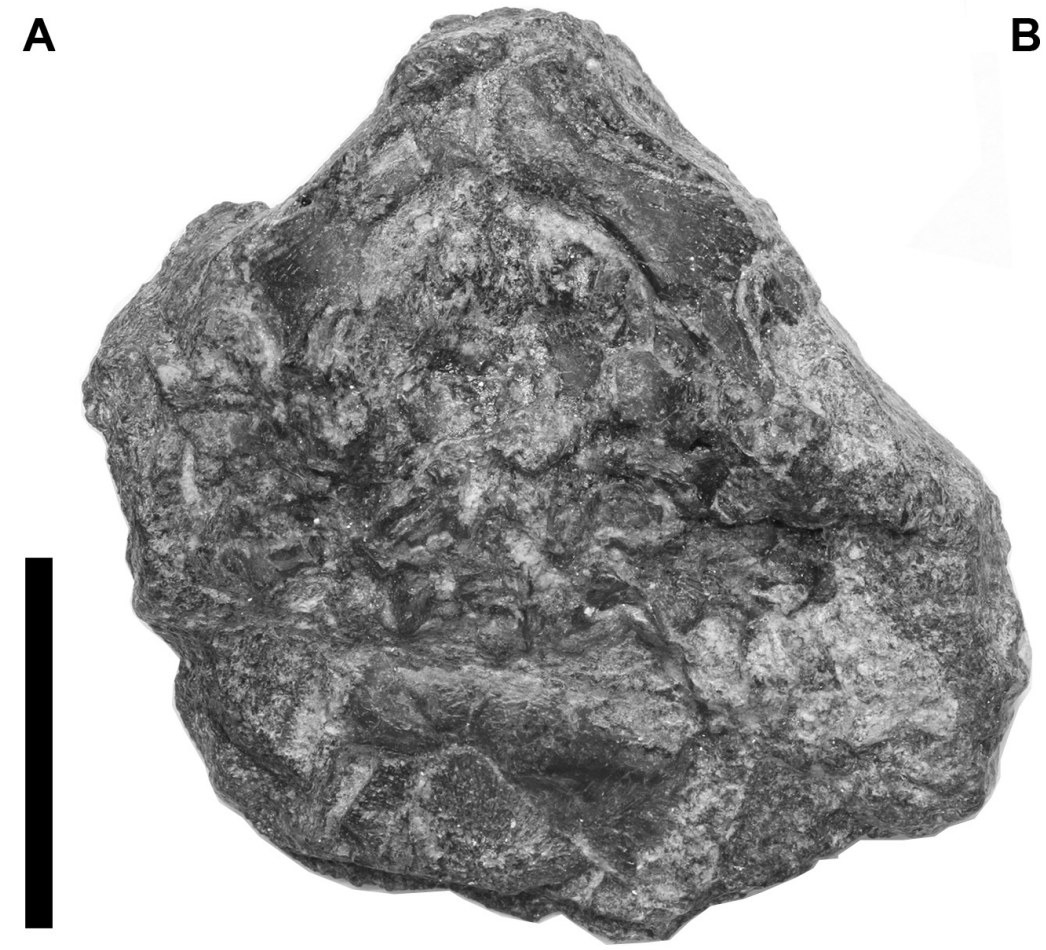

B

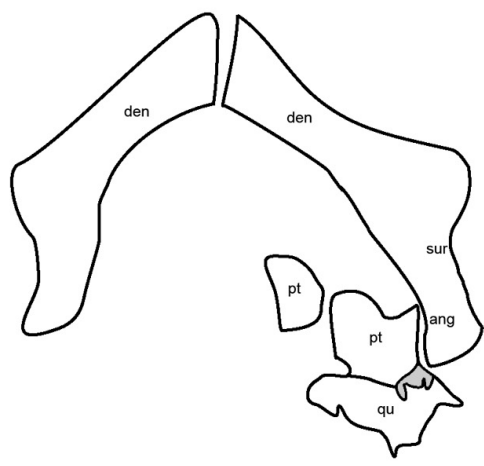

Figure 3. Ventral and ventrolateral view of the skull and lower jaw of CPCA 3560. Scale bar $=20 \mathrm{~mm}$.

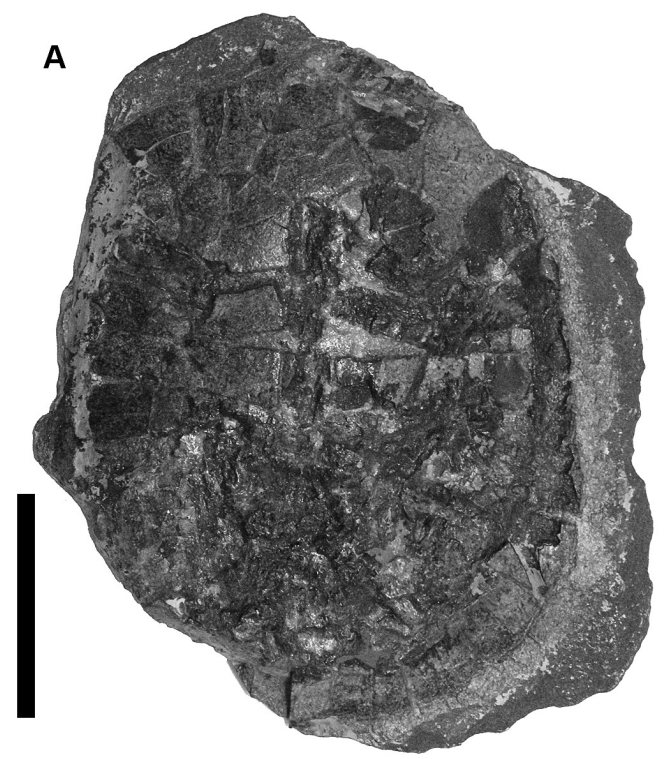

B
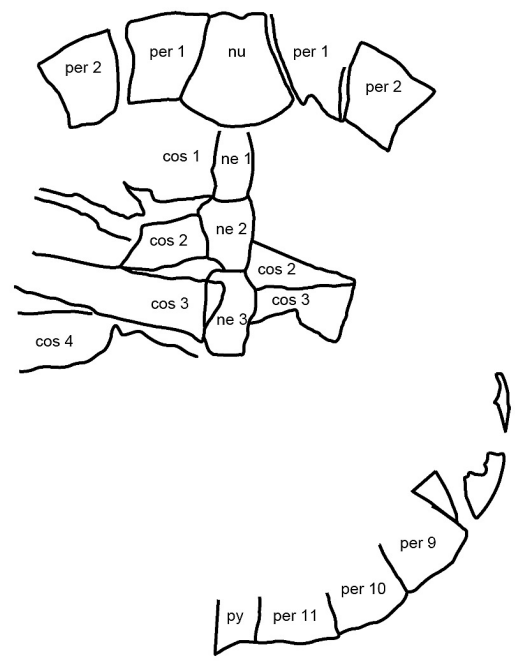

Figure 4. Dorsal view of the carapace of CPCA 3560: photo (A) and outline (B) of preserved bones. Scale bar $=50 \mathrm{~mm}$. 

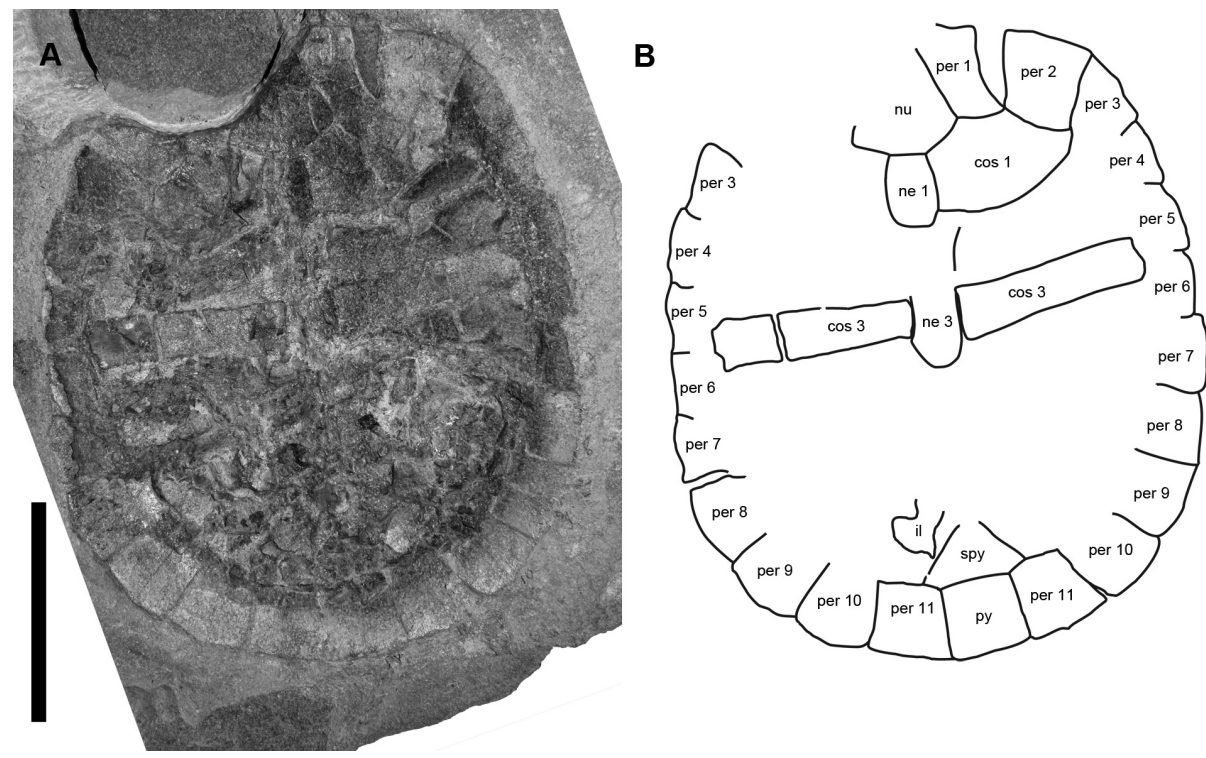

Figure 5. Counterpart of CPCA 3560: photo (A) and outline (B) of preserved bones. Scale bar $=50 \mathrm{~mm}$.

Table 1. Features of the carapace of the Testudines from the Santana Group.

\begin{tabular}{lccccc}
\hline \multicolumn{1}{c}{ Character } & Araripemys & Brasilemys & Cearachelys & Euraxemys & CPCA 3560 \\
\hline Carapacial fontanels & yes & no & no & no & no \\
Shell height & flattened & domed & domed & domed & domed \\
Neural number & 9 & 7 & 8 & 8 & at least five \\
Neural series complete to suprapygal & yes & no & yes & yes & $?$ \\
Deep nuchal emargination & yes & no & no & no & no \\
Surface texture of shell & with pits & smooth & smooth & smooth & smooth \\
\hline
\end{tabular}

\section{DISCUSSION}

Based on the condition of the pelvic girdle sutured to the shell, the specimen described here can be clearly regarded as a pleurodire turtle. Furthermore, the absence of a cervical scale indicates that CPCA 3560 represents a Pelomedusoides.

According to Oliveira et al. (2009) the following Pelomedusoides were described from the Araripe Basin: Araripemys barretoi Price, 1973, Brasilemys josai Lapparent de Broin, 2000, Cearachelys placidoi Gaffney, Campos \& Hirayama, 2001 and Euraxemys essweini Gaffney, Tong \& Meylan, 2006. Without presenting any argument, Fielding et al. (2005) interpreted CPCA 3560 as cf. Araripemys. However, this specimen differs from Araripemys in several features such as the absence of a nuchal emargination in the anterior portion of carapace and carapacial fontanels.

Brasilemys and other podocnemidids, possess a cavum pterygoidei, which is a synapomorphy of Podocnemidinura (sensu Gaffney et al., 2006); that feature is absent in CPCA 3560.

From all known Pelomedusoides from the Araripe Basin, CPCA 3560 has more similarities to Euraxemys essweini, including the outline and shape of the shell and the absence of a cavum pterygoidei. This genus is diagnosed by the morphology of the skull, which, unfortunately, is not sufficiently preserved in the Ipubi turtle for a more detailed comparison. The same is true for Cearachelys placidoi. Despite the fact that this specimen comes from a distinct stratigraphic level than any other turtle material from the Santana Group, it lacks a unique diagnostic feature or any particular combination of characters that would allow us to refer CPCA 3560 to any known species or establish a new taxon (see discussion in Kellner, 2010). Nonetheless, based on the comparisons above (Table 1), it is clear that the Ipubi turtle does not represent Araripemys (contra Fielding et al., 2005 ) - the most common turtle in the Araripe Basin (Oliveira \& Kellner, 2005; Oliveira, 2007; Naish, 2007) - or Brasilemys.

Although incomplete, CPCA 3560 expands the record of the turtle fauna of the Araripe Basin to the Ipubi Formation. It is also the first tetrapod collected in that stratigraphic unit showing the potential of new discoveries in those layers.

\section{ACKNOWLEDGMENTS}

The authors thanks D.A. Campos and R. Machado (Museu de Ciências da Terra, DNPM/RJ) and E.S. Gaffney and C. Mehling (American Museum of Natural History, NY) for the permission to analyze specimens under their care. Thanks to J. Silva for the preparation. B. Maciel and J. Silva are thanked by molding of the specimen CPCA 3560. For comments and improvement to the manuscript, we would like to thank F. Lapparent de Broin, Eugene S. Gaffney and Annie Hsiou. This project was partially funded by the Coordenação de Aperfeiçoamento de Pessoal de Nível Superior (CAPES) and Conselho Nacional de Desenvolvimento Científico e Tecnológico (CNPq, no. 140812/2007-5 to GRO, and 307276/ 2009-0 to AWAK), and Fundação Carlos Chagas Filho de Amparo à Pesquisa do Estado do Rio de Janeiro (FAPERJ, no. E-26/102.779/2008 to AWAK). 


\section{REFERENCES}

Assine, M.L. 1992. Análise estratigráfica da Bacia do Araripe, Nordeste do Brasil. Revista Brasileira de Geociências, 22(3):289-300.

Assine, M.L. 2007. Bacia do Araripe. Boletim de Geociências da Petrobrás, 15(2):371-389.

De La Fuente, M.S. \& Iturralde-Vinent, M. 2001. A new pleurodiran turtle from the Jagua Formation (Oxfordian) of western Cuba. Journal of Paleontology, 75:860-869. doi:10.1666/0022-3360

Dentzien-Dias, P.C.; Figueiredo, A.E.Q.; Pinheiro, F. \& Schultz, C. 2010. Primeira evidência icnológica de um tetrápode natante no Membro Crato (Cretáceo Inferior), Formação Santana (Bacia do Araripe, Nordeste do Brasil). Revista Brasileira de Paleontologia, 13(3):257-260. doi:10.4072/rbp.2010.3.09

Fara, E.; Saraiva, A.A.F.; Campos, D.A.; Moreira, J.K.R.; Siebra, D.C. \& Kellner, A.W.A. 2005. Controlled excavations in the Romualdo Member of the Santana Formation (Early Cretaceous, Araripe Basin, northeastern Brazil): stratigraphic, palaeoenvironmental and palaeoecological implications. Palaeogeography, Palaeoclimatology, Palaeoecology, 218:145-160. doi:10.1016/j.palaeo.2004.12.012

Fielding, S.; Martill, D.M. \& Naish, D. 2005. Solnhofen-style soft-tissue preservation in a new species of turtle from the Crato Formation (Early Cretaceous, Aptian) of North-east Brazil. Palaeontology, 48:1301-1310. doi:10.1111/j.14754983.2005.00508.x

Gaffney, E.S.; Campos, D.A. \& Hirayama, R. 2001. Cearachelys, a new side-necked turtle (Pelomedusoides: Bothremydidae) from the Early Cretaceous of Brazil. American Museum Novitates, 3319:1-20. doi:10.1206/ 0003-0082(2001)319<0001:CANSNT>2.0.CO;2

Gaffney, E.S.; Tong, H. \& Meylan, P.A. 2006. Evolution of the side-necked turtles: the families Bothremydidade, Euraxemydidae, and Araripemydidae. Bulletin of the American Museum of Natural History, 300:1-698.

Kellner, A.W.A. 1987. Ocorrência de um novo crocodiliano no Cretáceo Inferior da Bacia do Araripe, Nordeste do Brasil. Anais da Academia Brasileira de Ciências, 59(3):219-232.

Kellner, A.W.A. 2010. Comments on the Pteranodontidae (Pterosauria, Pterodactyloidea) with the description of two new species. Anais da Academia Brasileira de Ciências, 82(4):1063-1084. doi:10.1590/S0001-37652010000400025

Kellner, A.W.A. \& Campos, D.A. 1999. Vertebrate Paleontology in Brazil: a review. Episodes, 22(3):238-251.

Kellner, A.W.A. \& Campos, D.A. 2000. Brief review of dinosaur studies and perspectives in Brazil. Anais da Academia Brasileira de Ciências, 72(4):509-538. doi:10.1590/S000137652000000400005

Kischlat, E.-E. \& Campos, D.A. 1990. Some osteological aspects of Araripemys barretoi Price, 1973 (Chelonni, Pleurodira, Araripemydidae): In: SIMPÓSIO SOBRE A BACIA DO ARARIPE E BACIAS INTERIORES DO NORDESTE, 1, 1990. Anais, Crato, DNPM/URCA/SBP, p. 387-400.

Lapparent de Broin, F. De. 2000. The oldest pre-Podocnemidid turtle (Chelonii, Pleurodira), from the early Cretaceous, Ceará state, Brasil, and its environment. Treballs del Museu de Geologia de Barcelona, 9:43-95.

Lapparent de Broin, F. \& Murelaga, X. 1999. Turtles from the Upper Cretaceous of Laño (Iberian Peninsula). Estudios del Museo de Ciencias Naturales de Alava, 14:135-211.

Maisey, J.G. 1991. Santana fossils: an illustrated atlas. 1c ed. Neptune, T.F.H. Publications, 459 p.

Meylan, P.A. 1996. Skeletal morphology and relationships of the
Early Cretaceous side-necked turtle, Araripemys barretoi (Testudines: Pelomedusoides: Araripemydidae), from the Santana Formation of Brazil. Journal of Vertebrate Paleontology, 16(1):20-33.

Meylan, P.A.; Gaffney, E.S. \& Campos, D.A. 2009. Caninemys, a new side-necked turtle (Pelomedusoides: Podocnemididae) from the Miocene of Brazil. American Museum Novitates, 3639:126. doi:10.1206/608.1

Naish, D. 2007. Turtles of the Crato Formation. In: D.M. Martill; G. Bechly \& R.F. Loveridge (eds.) The Crato fossil beds of Brazil: window into an ancient world, Cambridge University Press, p. 452-457.

Neumann, V.H. \& Cabrera, L. 1999. Una nueva propuesta estratigráfica para la tectonosecuencia post-rifte de la Cuenca de Araripe, Nordeste de Brasil. SIMPÓSIO SOBRE O CRETÁCEO DO BRASIL, 5, 1999. Anais, Serra Negra, UNESP, p. 279-285.

Oliveira, G.R. 2007. Aspectos tafonômicos de Testudines da Formação Santana (Cretáceo Inferior), Bacia do Araripe, Nordeste do Brasil. Anuário do Instituto de Geociências, 30(1):83-93.

Oliveira, G.R. \& Kellner, A.W.A. 2005. Note on a plastron (Testudines, Pleurodira) from the Lower Cretaceous Crato Member, Santana Formation, Brazil. Arquivos do Museu Nacional, 63(3):523-528.

Oliveira, G.R. \& Kellner, A.W.A. 2007. A new side-necked turtle (Pleurodira, Pelomedusoides) from the Santana Formation (Early Cretaceous), Araripe Basin, northeastern Brazil. Zootaxa, 1425:53-61.

Oliveira, G.R. \& Romano, P.S.R. 2007. Histórico dos achados de tartarugas fósseis do Brasil. Arquivos do Museu Nacional, 65(1):113-133.

Oliveira, G.R.; Romano, P.S.R.; Azevedo, S.A.K. \& Kellner, A.W.A. 2009. The first Podocnemidera remains (Testudines, Pleurodira) from the Crato Formation, Araripe Basin, Brazil: In: GAFFNEY TURTLE SYMPOSIUM, 1, 2009. Drumheller, Royal Tyrrell Museum, p. 130-140.

Pons, D.; Berthou, P.Y. \& Campos, D.A. 1990. Quelques observations sur la palynologie de l'Aptien supérieur et de l'Albien do bassin d'Araripe (N-E du Brasil): In: SIMPÓSIO SOBRE A BACIA DO ARARIPE E BACIAS INTERIORES DO NORDESTE, 1, 1990. Anais, Crato, DNPM/URCA/SBP, p. 142-252.

Ponte, F.C. \& Appi, C.J. 1990. Proposta de revisão da coluna litoestratigráfica da Bacia do Araripe: In: CONGRESSO BRASILEIRO DE GEOLOGIA, 36, 1990. Anais, Natal, SBG, p. 211-226.

Ponte, F.C. \& Ponte Filho, F.C. 1996. Evolução tectônica e classificação da Bacia do Araripe: In: SIMPÓSIO SOBRE O CRETÁCEO DO BRASIL, 4, 1996. Resumos Expandidos, Rio Claro, UNESP, p. 123-133.

Price, L.I. 1973. Quelônio Amphichelydia no Cretáceo Inferior do Nordeste do Brasil. Revista Brasileira de Geociências, 3(2):84-95.

Schleich, H.H. 1990. Neues material zu Araripemys barretoi Price 1973 (Testudines: Pleurodira). Mitteilungen der Bayerischen Staatssammlung für Paläontologie und Historische Geologie, 30:39-49.

Silva, M.A.M. 1988. Evaporitos do Cretáceo da Bacia do Araripe: ambientes de deposição e história diagenética. Boletim de Geociências, 2(1):53-63.

Valença, L.M.M.; Neumann, V.H. \& Mabesoone, J.M. 2003. An overview on Callovian-Cenomanian intracratonic basins of Northeast Brazil: onshore stratrigraphic record of the opening of the southern Atlantic. Geologica Acta, 1:261-275.

Received in October, 2010; accepted in December, 2010. 